\title{
DINAMIKA KUALITAS AUDIT DI PERBANKAN SYARIAH DI INDONESIA
}

\author{
Riani dan Sepky Mardian \\ Program Studi Akuntansi Syariah \\ Sekolah Tinggi Ekonomi Islam SEBI \\ Email:rianiaza021@gmail.com; sepky.mardian@gmail.com
}

\begin{abstract}
This study discusses and understands the competence and independence of auditors on audit quality in sharia banking in Indonesia. While in the discussion the authors analyze the things that are deemed related to the competence and independent audit of auditor tenure or rotation seen through two post-KMK regime and post Act No. 5, Audit firm reputation by looking at audit firm size, audit fees, and auditor competencies determined through background education, certification, experience of work, and frequency of training that followed. The result of the research shows that the limitation of audit tenure does not decrease the quality of audit in sharia banking, the dynamics of audit quality is formed from independent relationship and auditor competence depends on the maximum level of audit.
\end{abstract}

Keywords: $\quad$ audit quality, auditor independence, competence of auditors

\section{PENDAHULUAN}

Dekade terakhir menunjukkan lebih dari $20 \%$ pertumbuhan industri keuangan syariah, yang salah satunya diprakarsai oleh kehadiran perbankan syariah. Perkembangan perbankan syariah cukup pesat dari tahun ke tahun. Secara institusional perkembangan bank syariah kini mulai mengalami kemajuan yang sangat pesat. Menurut Statistik Perbankan Syariah per Desember 2016 mencatat bahwa jumlah Bank Umum Syariah (BUS) sebanyak 13 bank, jumlah Unit Usaha Syariah (UUS) sebanyak 21, Bank Pembiayaan Rakyat Syariah (BPRS) sebanyak 166 bank dan jaringan kantor sebanyak 2.654. Sementara itu, dari sisi total Aset, Pembiayaan, dan penghimpunan Dana Pihak Ketiga (DPK) perbankan syariah khususnya BUS dan UUS - dalam milyar rupiah berturut-turut sebesar Rp 356.504, Rp 234.643, Rp 279.335 yang dilaporkan oleh Otoritas Jasa Keuangan(2016).

Lembaga keuangan syariah khususnya perbankan syariah perlu memiliki model tata kelola yang handal dan strategi yang tepat untuk mendorong pelaksanaan shariah compliance yang kuat dan efektif. Pemenuhan kepatuhan syariah tersebut bertujuan menjaga citra publik khususnya kepentingan stakeholderdengan harapan mewujudkan kegiatan ekonomi yang sesuai dengan prinsip-prinsip syariah, kegiatan investasi yang bebas dari riba (Akbar, Mardian, \& Anwar, 2015, hal. 102). Suatu rangkaian proses pemenuhan kebutuhan shariah compliance tersebut adalah pelaksanaan audit syariah. 
Audit syariah dilakukan untuk memastikan bahwa bank syariah dapat menegakkan tata kelola syariah dan pada saat yang samameningkatkan kepercayaan pemangku kepentingan. Namun, seringkali muncul kemungkinan masalah perbedaan kepentingan antara manajemen dan pemakai laporan keuangan mengenai kesenjangan informasi yang disediakan. Pada akhirnya peran pihak ketiga yang kompeten dan independen dibutuhkan untuk melakukan pemeriksaan terhadap laporan keuangan (Baker dan AlThuneibat, 2011).

Akuntan publik merupakan profesi yang paling tepat sebagai pihak ketiga dan berperan sebagai auditor untuk melaksanakan fungsi audit syariah. Jasa akuntan publik dibutuhkan untuk memberi jaminan relevan dan dapat diandalkannya laporan keuangan perusahaan, membuktikan laporan keuangan yang disajikan manajemen terbebas dari salah saji material, sehingga dapat meningkatkan kepercayaan pihak-pihak bersangkutan terkait perusahaan tersebut. Namun, munculnya kasus-kasus skandal akuntansi dalam tahun-tahun belakangan ini memberikan bukti lebih jauh tentang kegagalan audit yang membawa akibat serius bagi masyarakat bisnis. Berdasarkan laporan Association of Certified Fraud Examiners (ACFE) tahun (2016) bahwa jenis kecurangan yang paling banyak adalah kecurangan laporan keuangan fraudulent statementsyangmenyumbang kerugian paling besar daripada kecurangan lainnya.

Kasus pada Enron Corporation, dimana sebelumnya opini wajar tanpa pengecualian yang diberikan oleh KAP Arthur Anderson (AA) dinyatakan pailit, padahal pengauditan keuangan Enron oleh AA sudah berjalan selama hampir 20 tahun. Kasus serupa terjadi di Indonesia yang dimuat dalam (Kompas, 2010) yaitu seorang akuntan publik bernama Biasa Sitepu diduga terlibat dalam kasus korupsi kredit macet, karena keikutsertaan dalam pembuatan pemalsuan laporan keuangan Raden Motor guna memperoleh pinjaman senilai 52 milyar dari BRI Cabang Jambi tahun 2009 lalu. Tentu saja ini merupakan pelanggaran profesionalisme dan etika profesi.

Berdasarkan kasus yang terjadi pada akuntan publik ini menyebabkan integritas, objektivitas dan kinerja dari seorang auditor mulai diragukan. Padahal, profesi akuntan publik merupakan profesi kepercayaan masyarakat yang bebas dari pelanggaran kecurangan dan kode etik profesi akuntan publik. Hal tersebut merupakan tantangan akuntan publik memerhatikan kualitas audit yang dihasilkannya dengan harapan mengembalikan kepercayaan entitas maupun masyarakat. Kualitas audit merupakan konsep yang menunjukkan bahwa auditor dapat melaksanakan tugas secara profesional berdasarkan etika profesi, kompetensi, dan independensi (Junaidi dan Nurdiono, 2016 hal 01)

Menurut (Coram, et al, 2008), kualitas auditor adalah seberapa besar kemungkinan dari seorang auditor menemukan adanya unintentional/intentional error dari laporan keuangan perusahaan, serta seberapa besar kemungkinan temuan tersebut kemudian dilaporkan dan dicantumkan dalam opini audit. Dua konsep terpenting dari kualitas auditor adalah kompetensi dan independensi. Kedua hal tersebut berpengaruh 
langsung terhadap kualitas audit. Selanjutnya, kompetensi auditor terhadap kualitas audit diproyeksikan dengan pengalaman dan pengetahuan sedangkan independensi diproyeksikan dengan lama hubungan dengan klien (audit tenure), reputasi audit (ukuran KAP), fee audit.

Perdebatan mengenai rotasi audit atas batasan auditor tenur masih memuncak. Pendukung rotasi berpendapat bahwarotasi terhadap kualitas audit dapat meningkatkan independensi. Hal ini sesuai dengan temuan Gavious (2007) bahwa audit tenure antara auditor dan klien akan menimbulkan masalah independensi, sehingga memerlukan rotasi. Masalah independensi tersebut karena semakin panjang tenure, kualitas audit semakin turun yang diakibatkan oleh hubungan auditor dan manajemen terikat secara emosional sehingga manajemen memperoleh fleksibilitas yang lebih tinggi untuk membuat laporan keuangan sesuai dengan keingginannya. Penentang rotasi berpendapat bahwa rotasi akan menurunkan kompetensi karena kewajiban rotasi akan menimbulkan risiko pelaksanaan audit yang lebih besar, karena auditor belum familiar dengan bisnis klien yang mengakibatkan gagalnya audit pada tahun-tahun awal penugasan audit. Beberapa riset menemukan bukti bahwa tidak ditemukan perbedaan reaksi pasar atas auditor tenure maupun audit switch pada kualitas audit justru, audit tenure yang lamakan semakin meningkatkan kualitas auditor dengan meningkatnya kualitas laba, bahkan mudahnya menemukan fraud. Pertukaran audit akan meningkatkan biaya tambahan yang secara tidak langsung harus ditanggung oleh investor (Knechel \& Vanstraelen, 2007; Manry, Mock, \& Turner, 2008).

Berbagai pendapat diatas, penerapan ketentuan rotasi wajib bagi auditor telah diatur dalam (Peraturan Menteri Keuangan RI Nomor 172008 Jasa Akuntan Publik) tentang Jasa Akuntan Publik pasal 3 butir 1 mengenai pembatasan audit tenure. Peraturan rotasi wajib tersebut hanya berlaku sampai dengan tahun 2011, dimana dengan terbitnya (Undang-undang No. 5 Tahun 2011 Tentang Akuntan Publik) mengenai tidak adanya pembatasan audit tenure. Tidak konsistennya penetapan regulator mengenai rotasi audit terlihat dengan terbitnya (Peraturan Pemerintah RI Nomor 25 Tahun 2015) tentang praktik akuntan publik pada pasal 11 yang mengatur pemberian jasa audit oleh Akuntan Publik maupun KAP dibatasi paling lama untuk 5 (lima) tahun buku berturut-turut, dan dapat kembali memberikan jasa audit setelah dua tahun buku tidak memberikan jasa auditnya. Berdasarkan peraturanperaturan resmi tersebut diharapkan akan meningkatkan independensi auditor baik secara tampilan maupun maupun fakta.

Para peneliti berupaya menenemukan faktor-faktor pembentuk kualitas audit, berdasarkan data yang dikutip dari (Agoes, 2012, hal. 67) bahwa terdapat 52 kasus pelanggaran kode etik yang dilakukan oleh akuntan publik selama 2004-2009 dengan aspek pelanggaran terbanyak yaitu kualitas audit dibandingkan dengan aspek lainnya.

Sebagai salah satu profesi mendukung kegiatan dunia usaha, meningkatnya pertumbuhan perbankan syariah, kebutuhan pengguna jasa akuntan publik akan semakin meningkat pula, terutama kebutuhan atas kualitas informasi keuangan yang digunakan sebagai salah satu pertimbangan 
pengambilan keputusan. Dengan demikian, Akuntan Publik dituntut untuk menantiasa meningkatkan kompetensi dan profesionalisme agar dapat memenuhi kebutuhan tersebut dan mengemban kepercayaan publik. Pemenuhan kebutuhan jasa audit atas entitas syariah

Penelitian ini membahas kualitas audit dari independen dan kompetensi auditor, dimana berdasarkan berbagai kontroversi hasil riset mengenai hubungan pembatasan tenur/wajib rotasi, reputasi auditor, fee audit serta kompetensi auditor terhadap kualitas audit yang tinggi, sedangkan auditor perbankan syariah harus menjamin relevan (relevance) atau dapat diandalkan (reliable) laporan keuangan, terpenuhinya shariah compliancedan untuk meningkatkan kepercayaan publik maupun pemangku kepentingan sehingga peneliti lebih lanjut membahas bagaimana dinamika kualitas audit perbankan syariah di Indonesia.

\section{KAJIAN TEORI}

\subsection{KUALITAS AUDIT}

Auditing adalah proses pengumpulan dan evaluasi bukti mengenai suatu informasi untuk menetapkan dan melaporkan tingkat kesesuaian antara informasi tersebut dengan kriterianya. Auditing hendaknya dilakukan oleh seorang yang kompeten dan independen (Elder, Beasley, \& Arens, 2009, hal. 4). Suatu jasa profesional yang independen dan obyektif tersebut adalah akuntan publik yang diperlukan untuk menilai kewajaran laporan akuntan yang disajikan oleh manajemen. Para pengguna audit mengharapkan bahwa laporan keuangan yang telah diaudit oleh akuntan publik bebas dari salah saji material, dapat dipercaya kebenarannya untuk dijadikan sebagai dasar pengambilan keputusan dan telah sesuai dengan prinsip-prinsip akuntansi yang berlaku di Indonesia (Saputra, 2012).

Audit memiliki fungsi sebagai proses untuk mengurangi ketidaklarasan informasi yang terdapat antara manajer dan para pemangku kepentingan seperti pemegang saham maupun pihak luar untuk memberikan pengesahan terhadap laporan keuangan. Audit syariah lebih kompleks karena tidak hanya menjamin relevan (relevance) dan dapat diandalkan (reliable) laporan keuangan, tetapi pemenuhan terhadap prinsip-prinsip syariah sebagai konsekuensi label syariah.

Laporan auditor merupakan media komunikasi formal untuk mengkomunikasikan kepada pihak-pihak yang berkepentingan tentang apa yang telah dilakukan oleh auditor dan kesimpulan yang dicapainya atas audit laporan keuangan (Rahayu dan Suharti, 2010, hal. 73). Artinya laporan tersebut akan memberikan informasi kepada publik mengenai mengenai kewajaran laporan keuangan auditan. Hasil laporan auditor digunakan oleh para pengguna laporan keuangan terutama para pemegang saham untuk mengambil keputusan. Oleh karena itu, kualitas audit memiliki peranan penting dalam pemberian opini laporan keuangan. 

yaitu:

Hal-hal yang dianggap mempunyai hubungan dengan kualitas audit

a. Lama waktu auditor telah melakukan pemeriksaan terhadap suatu perusahaan, semakin lama seorang auditor melakukan audit pada klien yang sama maka kualitas audit yang dihasilkan akan semakin rendah,

b. Jumlah klien, semakin banyak jumlah klien maka kualitas audit akan semakin baik karena auditor dengan jumlah klien yang banyak akan berusaha menjaga reputasinya,

c. Kesehatan keuangan klien, semakin sehat kondisi keuangan klien maka akan ada kecenderungan klien tersebut untuk menekan auditor agar tidak mengikuti standar, dan

d. Review oleh pihak ketiga, kualitas audit akan meningkat jika auditor tersebut mengetahui bahwa hasil pekerjaannya akan direview oleh pihak ketiga Alim, Hapsari, \& Purwanti, 2007).

\subsection{INDEPENDENSI}

Salah satu faktor yang mendasari keberadaan jasa audit adalah independensi. Nilai audit sangat tergantung pada persepsi publik akan independen yang dimiliki auditor. Independen dalam audit berarti mengambil sudut pandang yang tidak bias dalam melakukan ujian audit, mengevaluasi hasilnya dan membuat laporan audit. Proses audit yang independen didasarkan pada kerangka norma, konsep, prosedur, praktik pelaporan, dan etika auditor. Penelitian yang dilakukan oleh Shockley (1981) seperti dikutip (Agoes, 2012, hal. 54) meneliti 4 faktor yang mempengaruhi independensi, yaitu persaingan antar akuntan publik, pemberian jasa konsultasi manajemen kepada klien, ukuran KAP, dan lamanya hubungan audit.

Penelitian yang dilakukan oleh (Tjun, Marpaung, \& Setiawan, 2012) mengukur independensi diukur melalui lama hubungan dengan klien, tekanan dari klien, telaah dari rekan auditor dan pemberian jasa non audit. Independensi memiliki hubungan dengan kualitas audit hal tersebut sesuai dengan penelitian oleh (Singgih dan Bawono, 2010), Independensi berpengaruh signifikan terhadap kualitas audit.

a. Lama Hubungan dengan Klien (Audit Tenure).

Audit Tenure adalah masa jabatan dari Kantor Akuntan Publik dalam memberikan jasa audit terhadap kliennya. Ketentuan audit tenure telah dijelaskan dalam Menteri Keuangan RI pada tanggal 5 Februari (2008) menerbitkan Peraturan Menteri Keuangan No. 17/PMK.01/2008. Namun, peraturan tersebut tidak berlaku lagi dengan keluarnya peraturan baru tahun 2011 yaitu Undang-Undang Republik Indonesia Nomor 5 Tahun (2011) tentang Akuntan Publik dimana peraturan tersebut tidak mengatur rotasi audit.

Namun, berbagai argumen pendukung dan penolakan pembatasan audit tenure (rotasi wajib) bagi auditor. Beberapa peneliti sebelumnya seperti 
penelitian yang dilakukan oleh (Hartadi, 2012) telah membuktikan bahwa fee, rotasi audit, reputasi berpengaruh terhadap kualitas audit. Penelitian yang dilakukan oleh (Giri, 2010) membuktikan bahwa tenur audit tidak berpengaruh terhadap kualitas audit. Indikasi penugasan audit yang terlalu lama kemungkinan dapat mendorong akuntan publik kehilangan independensinya karena akuntan publik tersebut merasa puas, kurang inovatif, serta kurang ketat dalam melaksanakan prosedur audit. Sebaliknya penugasan audit yang lama kemungkinan dapat pula meningkatkan independensi karena akuntan publik sudah familiar dengan bisnis klien, pekerjaan dapat dilaksanakan dengan efisien dan lebih tahan terhadap tekanan klien.

Ada dua alasan mendasar yang mendukung rotasi mandatori, yaitu pertama independensi auditor dapat dirusak oleh hubungan jangka panjang dengan manajer perusahaan, kedua kualitas dan kompetensi kerja auditor cenderung menurun secara signifikan dari waktu ke waktu. Beberapa peneliti lebih cenderung melihat pengaruh hubungan audit tenure dengan kualitas audit secara linier positif dan negatif, sehingga perlunya melihat hubungan secara kuadratik yaitu ada titik optimal dalam pemberian jasa audit, penelitian empiris dengan jangka waktu rotasi bersifat konstan yang dapat meningkatkan kualitas audit.

b. Reputasi KAP berdasarkan Ukuran KAP terhadap Kualitas Audit.

Reputasi KAP menunjukkan prestasi dan kepercayaan publik yang disandang auditor atas nama besar yang dimiliki auditor, bersifat perspektif masa lalu. Reputasi juga dianggap sebagai sudut pandang klien atas pekerjaan auditor/akuntan publik. Reputasi dikaitkan dengan ukuran KAP dengan skala besar dan kecil. Reputasi auditor diukur melalui frekuensi auditor tersebut disewa oleh klien.

Menurut De Angelo dalam Hariwibowo (2013) bahwa auditor yang bekerja untuk ukuran KAP skala besar memiliki insentif yang lebih untuk menghindari kritikan reputasi dibandingkan pada auditor skala kecil. Auditor skala besar cenderung untuk mengungkapkan masalah-masalah yanng ada karena lebih kuat menghadapi risiko, juga lebih mudah mendeteksi dan melaporkan masalah going concern kliennya. Beberapa faktor yang mempengaruhi auditor dalam memberikan opini going concern diantaranya faktor keuangan, mitigasi evidence, disclosure risiko, reputasi auditor, tenure auditor dan ukuran perusahaan (Junaidi dan Nurdiono, 2016).

c. Fee Audit

Fee audit adalah besaran biaya yang diterima oleh auditor dengan mempertimbangkan berbagai hal seperti kompleksitas jasa yang diberikan, tingkat keahlian, struktur biaya KAP yang bersangkutan dan pertimbangan biaya profesional lainnya. Akuntan publik tidak diperkenankan mendapatkan klien dengan cara menawarkan fee yang dapat merusak citra profesi (Agoes, 2012, hal. 46). 


\subsection{KOMPETENSI}

Menurut De Angelo dalam (Alim, Hapsari, \& Purwanti, 2007), bahwa kompetensi auditor adalah kemampuan auditor untuk menemukan kesalahan sistem akuntansi keuangan kliennya. Dalam pengauditan, seorang auditor harus melaksankan jasa profesionalnya dengan kehati-hatian, kompetensi dan ketekunan, serta auditor harus mempertahankan sikap kompetenya. Kompetensi teknis seorang auditor yang melaksanakan audit ditentukan oleh tiga faktor yaitu:

a. Pendidikan formal dalam bidang akuntansi disuatu perguruan tinggi termasuk ujian profesi auditor.

b. Pelatihan yang bersifat praktis dan pengalaman dalam bidang auditing.

c. Pendidikan professional yang berkelanjutan selama menekuni karier auditor professional.

\section{PEMBAHASAN}

Tabel dibawah ini menampilkan rata-rata jumlah annual report masingmasingbank syariah sebanyak 6 sampai dengan 7 laporan selama tahun 20082016. Jumlah laporan tersebut harus memenuhi kriteria analisis yang diperlukan. Informasi lain yang dapat kita ketahui dari tabel di atas adalah kelengkapan pengungkapan laporan independen pada laporan tahunan bank syariah cukup baik yaitu sekitar $91 \%$ dari 12 bank syariah atas 79 laporan tahunan periode 2008 sampai dengan 2016. Hal tersebut menunjukkan bahwa tingkat pelaporan bank syariah atas akuntabilitas terhadap transparansi cukup baik, sedangkan 9\% atas ketidaklengkapan pengungkapan Akuntan Publik pada laporan keuangan publikasi.

Tabel 1. Jumlah Laporan Tahunan Bank Syariah Periode Tahun 2008-2016

\begin{tabular}{clccc}
\hline No. & Nama Bank Syariah & $\begin{array}{c}\text { Jumlah } \\
\text { Laporan } \\
\text { Tahunan }\end{array}$ & $\begin{array}{c}\text { Lengkap \& } \\
\text { diolah }\end{array}$ & $\begin{array}{c}\text { Tidak } \\
\text { Mengungkap } \\
\text { AP }\end{array}$ \\
\hline 1 & BTPN Syariah & 3 & 3 & 0 \\
\hline 2 & Victoria Syariah & 5 & 5 & 0 \\
\hline 3 & BNI Syariah & 6 & 5 & 1 \\
\hline 4 & Panin Syariah & 6 & 6 & 0 \\
\hline 5 & BCA Syariah & 6 & 6 & 0 \\
\hline 6 & Maybank Syariah & 6 & 6 & 3 \\
\hline 7 & BJB Syariah & 7 & 4 & 1 \\
\hline 8 & BRI Syariah & 7 & 6 & 0 \\
\hline 9 & BSM & 8 & 8 & 0 \\
\hline 10 & Mega Syariah & 8 & 7 & 7 \\
\hline 11 & Bukopin Syariah & 8 & 8 & 1 \\
\hline 12 & BMI & 9 & 8 & 72 \\
\hline
\end{tabular}




\begin{tabular}{cccc}
\hline Prosentase & $100 \%$ & $91 \%$ & $9 \%$ \\
\hline Sumber: Data diolah dari website masing-masing bank syariah
\end{tabular}

Sumber: Data diolah dari website masing-masing bank syariah

Persepsi para pengguna laporan keuangan atas kualitas audit adalah bagaimana persepsi mereka atas independensi dan kompetensi auditor. Laporan auditor independen adalah bentuk komunikasi kepada masyarakat mengenai kewajaran laporan manajemen. Dapat disimpulkan bahwa auditor memiliki peranan yang penting dalam pengesahan laporan keuangan bank syariah, karena kebutuhan akan kualitas informasi didalamnya dapat digunakan sebagai salah satu dasar pengambilan keputusan.

Tabel 2. Sebaran Audit Tenur \& Rotasi Wajib Auditor

\begin{tabular}{clll}
\hline \multirow{2}{*}{ NO. } & & \multicolumn{1}{c}{ Pasca KMK } & \multicolumn{1}{c}{ Paska UU No. 5 } \\
\cline { 3 - 4 } & & Thn 2008-2011 & Thn 2012-2016 \\
\hline 1. & BSM & 1 KAP tetap & 2 KAP \\
\hline 2. & BMI & 1 KAP tetap & 4 KAP \\
\hline 3. & Mega Syariah & 1 KAP tetap & 2 KAP \\
\hline 4. & BRI Syariah* & 1 KAP tetap & 1 KAP tetap \\
\hline 5. & BJB Syariah* & 1 KAP tetap & 2 KAP \\
\hline 6. & Bukopin Syariah & 2 KAP & 3 KAP \\
\hline 7. & BNI Syariah* & 1 KAP tetap & 1 KAP tetap \\
\hline 8. & BCA Syariah* & 1 KAP tetap & 1 KAP tetap \\
\hline 9. & Panin Syariah* & 1 KAP tetap & 1 KAP tetap \\
\hline 10. & BTPN Syariah & - & 1 KAP tetap \\
\hline 11. & Vicoria Syariah & - & 4 KAP \\
\hline 12. & Maybank Syariah & - & 1 KAP tetap \\
\hline
\end{tabular}

Sumber: Data diolah dari website masing-masing bank umum syariah

Berdasarkan tabel 2 diatas dapat disimpulkan bahwa penggunaan jasa audit pada satu KAP tetap lebih dominan pada pasca KMK tahun 2008-2011, sedangkan pasca UU No.5 tahun 2012-2016 penggunaan jasa audit oleh KAP bervariasi. Terlihat dari tabel diatas bahwa hampir seluruh bank syariah pasca KMK menggunakan audit tenur yang panjang. Bank syariah memilih KAP audit yang sama untuk 2 sampai dengan 4 tahun buku berturut-turut. Informasi lain yang dapat disimpulkan dari tabel diatas adalah pasca UU nomor 5 yang berlaku tahun 2012-2016 penggunaan jasa audit bervariasi. Dari 12 bank syariah, 6 bank diantaranya lebih memilih satu KAP yang tetap dalam kurun tersebut, sedangkan 6 bank lainnya tidak mempertahankan audit tenure. 
Secara keseluruhan bahwa bank syariah lebih memilih audit tenur yang lama daripada melakukan rotasi audit setiap tahun. Hasil analisis ini didukung oleh penelitian sebelumnya oleh ( Manry, Mock, \& Turner, 2008) mengemukakan bahwa, tenur auditor berpengaruh negatif terhadap kualitas audit yang diukur dengan akrual. Pendapat ini kemudian senada dengan pendapat penelitian terdahulu lainnya pada tahun 2002 hingga 2007. Penelitian yang dilakukan oleh (Giri, 2010) mengungkapkan bahwa pembatasan tenur tidak merusak kualitas audit, karena beberapa alasan yaitu tenure KAP yang lama akan meningkatkan pengetahuan yang cukup bagi auditor untuk melakukan tugasnya secara profesional dan lebih teliti, alasan lain adalah menekan cost yang harus dibayarkan oleh klien.

Namun permasalahan yang terjadi, ketika berbicara tentang sebenarnya mana yang lebih efektif dalam peningkatan kualitas audit dengan mewajibkan rotasi audit/pembatasan jasa audit atau penerapan audit tenur yang panjang. Berbagai peneliti terus mencoba melakukan perbaikan kualitas audit. Salah satu bukti empiris dalam penelitian yang dilakukan oleh (Fitriany et al., 2015) yang menguji pengaruh tenure, rotasi dan spesialisasi KAP terhadap kualitas audit sebelum dan sesudah regulasi rotasi KAP di Indonesia dengan menggunakan sampel bursa efek, hasil penelitiannya mendukung deskripsi analisis peneliti yaitu penerapan rotasi audit menurunkan kualitas audit pada sebelum dan sesudah regulasi. Oleh karenanya, dapat ditarik kesimpulan bahwa audit tenure pada perbankan syariah tidak menurunkan kualitas audit walaupun telah dilakukan adanya pembatasan/rotasi auditor, hal ini dikarenakan tidak adanya penurunan opini audit pasca KMK dan pasca UU Nomor 5.

Grafik 1. Penggunaan Jasa Audit KAP Selama Periode 2008-2016 Pada Bank Syariah

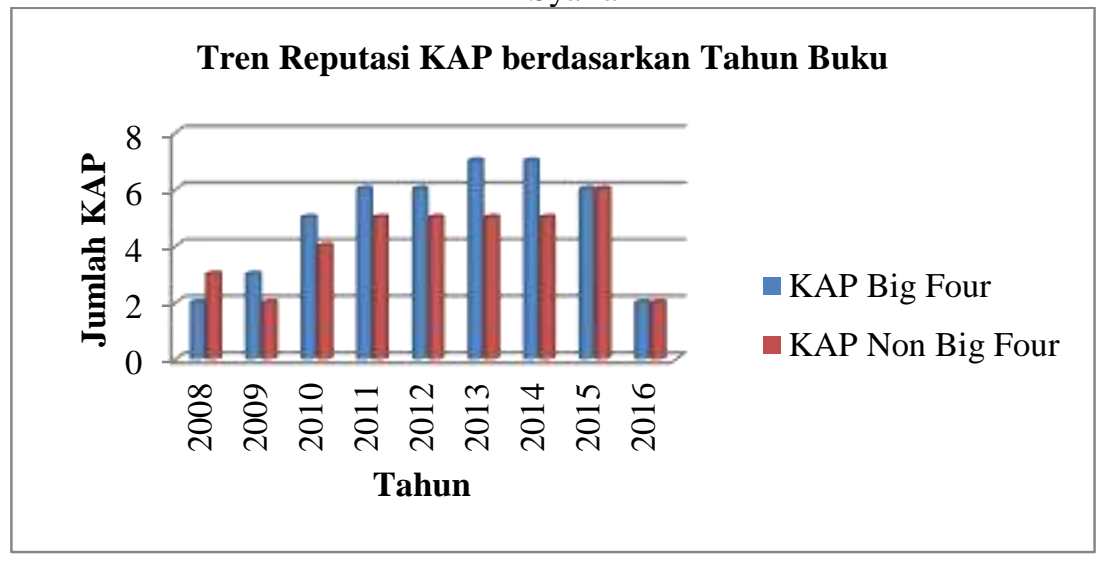

Sumber: Data diolah dari website masing-masing bank

Grafik diatas dapat dilihat bahwa dari tahun ke tahun penggunaan jasa audit KAP Big Four untuk jasa audit lebih meningkat dibandingkan KAP non-Big Four. Hal tersebut membuktikan bahwa pandangan klien dalam 
memilih auditor independen bertaraf Internasional untuk mengaudit laporan keuangan lebih tinggi.

Grafik 2. Tingkat Reputasi KAP

\section{Ukuran KAP Menurut Klien}

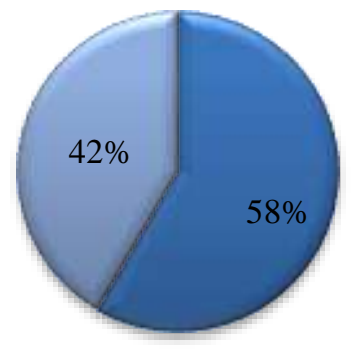

$\square$ KAP Big Four $\quad \square$ KAP Non Big 4

Sumber: Data diolah dari website masing-masing bank

Grafik diatas dapat dilihat bahwa 58\% atau sejumlah 7 bank syariah lebih memilih KAP berafiliasi internasional yang masuk kedalam kategori Big Four daripada penggunaan KAP non-Big Four yang bekerja sama dengan KAPA maupun KAP perorangan. Secara keseluruhan bahwa reputasi KAP Big Four masih menguasai pangsa pasar khususnya perbankan syariah. Ini menunjukkan bahwa ketertarikan terhadap KAP Big-Four masih kuat hal ini didukung dengan beberapa alasan yaitu pertama berdasarkan penelitian yang dilakukan oleh (Singgih \& Bawono, 2010) bahwa faktor yang paling dominan terhadap kualitas audit adalah independen. Kedua, independen auditor menjamin terpenuhinya kepatuhan syariah yang berdampak dalam jangka panjang terhadap peningkatan performa bank syariah, sehingga mampu meningkatkan citra baik bagi investor maupun publik. Ketiga, dari hubungan lamanya audit, dimungkinkan bahwa klien akan lebih percaya terhadap KAP sebelumnya mengaudit dan tidak ingin mengganti auditor. Keempat, munculnya skandal-skandal baru yang berasal dari kegagalan audit akibat pergantian auditor baru maka banyak bank syariah tetap mempertahankan dominannya terhadap KAP Big-Four. Kelima, KAP Big Four merupakan KAP yang memiliki banyak klien sehingga dimungkinkan ketika jumlah klien semakin banyak maka auditor akan menjaga reputasinya.

Berdasarkan uraian diatas, maka dapat disimpulkan bahwa ketertarikan terhadap KAP yang berafiliasi internasional masih kuat terutama didominasi oleh KAP the big four. Gambaran berbagai tabel dan grafik di atas disimpulkan bahwa reputasi KAP berafiliasi Internasional yang termasuk dalam kategori the big fourlebih dipertimbangkan daripada KAP non big four. Ini menunjukkan bahwa ukuran KAP memiliki hubungan dengan reputasi KAP dimata klien. Perbankan syariah lebih memilih KAP the big four dalam mengaudit laporan keuangan mereka, hal ini terepresentasi dari 
frekuensi auditor yang disewa oleh komite berwenang. Semakin tinggi frekuensi auditor disewa maka semakin tinggi pula reputasi auditor tersebut. Reputasi berpengaruh langsung terhadap independen auditor seperti yang ditemukan oleh Law (2008) dalam penelitiannya bahwa KAP big four lebih independen dari pada KAP non big four. Dengan demikian bahwa semakin tinggi reputasi auditor maka akan meningkatkan independen auditor, sehingga berdampak pada kualitas audit.

Grafik 3. Tingkat Fee Audit Periode 2011-2015

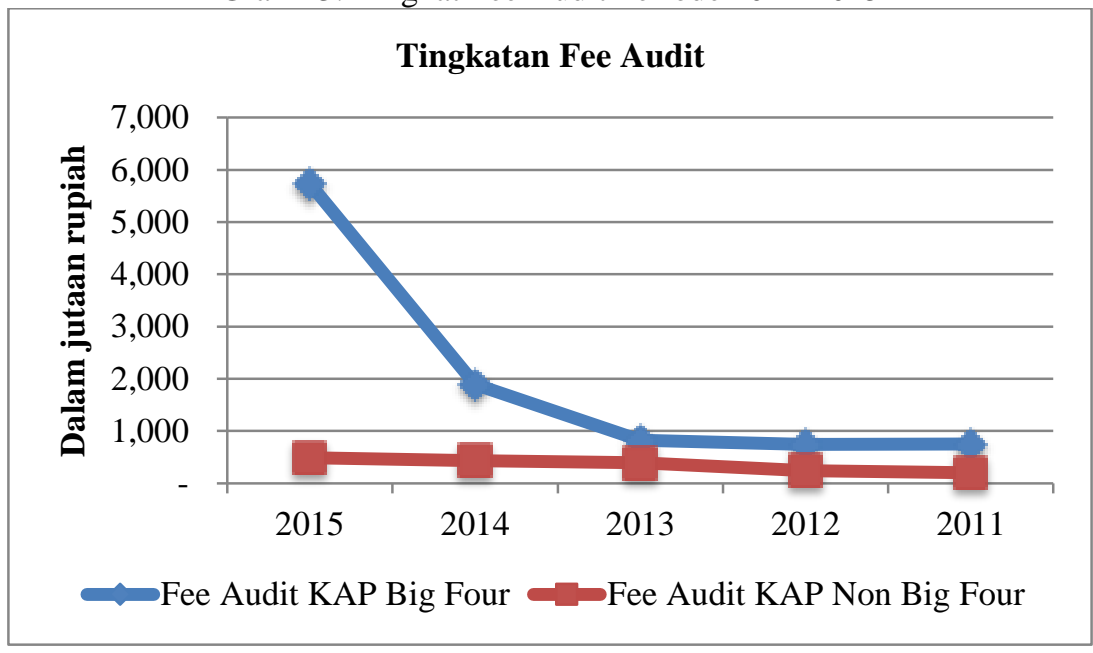

Sumber: Data diolah dari web bank bukopin syariah dan bank mandiri syariah

Dari grafik diatas dapat diketahui bahwa fee audit semakin tinggi setiap tahun. Besaran fee audit dapat diukur melalui struktur biaya KAP maupun ukuran KAP, dan juga kompleksitas jasa assurans atas resiko penugasan. Ukuran KAP big four memilki tingkat besaran fee yang lebih besar dibandingkan dengan KAP non big four. Dilema yang dihadapi KAP dengan meningkatnya fee adalah jika KAP menerima fee audit yang tinggi maka KAP akan menghadapi tekanan ekonomis untuk memberikan opini, ini menunjukkan terdapat pengaruh independensi terhadap integritas laporan keuangan. Hubungan independen tersebut didasari dengan alasan yaitu pada saat auditor bernegosiasi dengan manajen mengenai besaran tarif fee maka akan terjadi sikap empati, ketergantungan ekonomi terhadap klien, dan mengesampingkan kepentingan publik sehingga menurunkan kualitas audit. Beberapa penelitian sebelumnya mendukung gambaran ini yaitu penelitian (Hartadi, 2012; Pratistha \& Widhiyani, 2014) bahwa fee audit merupakan variabel yang paling dominan dan signifikan meningkatkan independensi auditor sehingga dapat meningkatkan kualitas audit. Namun, perlu ditekankan adalah bagaimana independensi auditor menekan risiko kualitas audit akibat besaran fee yang meningkat.

Secara keseluryhan bahwa masalah independensi auditor akan lebih ditemui ketika penggunaan jasa audit yang panjang diatas batas rotasi audit 
yang telah ditetapkan. Dinamika kualitas audit adalah audit tenure tidak menurunkan kualitas audit hal tersebut terlihat tidak adanya penurunan opini auditor dalam dua rezim tersebut. Peraturan rotasi wajib bagi auditor perlu mempertimbangkan kompleksitas dan ukuran entitas yang tidak mendukung pelaksanaan audit jangka pendek. Perlunya penetapan jangka waktu rotasi audit yang tepat dengan pembuktian empiris sehingga mampu meningkatkan independensi dan kompetensi untuk membentuk kualitas audit yang tinggi.

Grafik 4. Background Pendidikan Formal Akuntan Publik

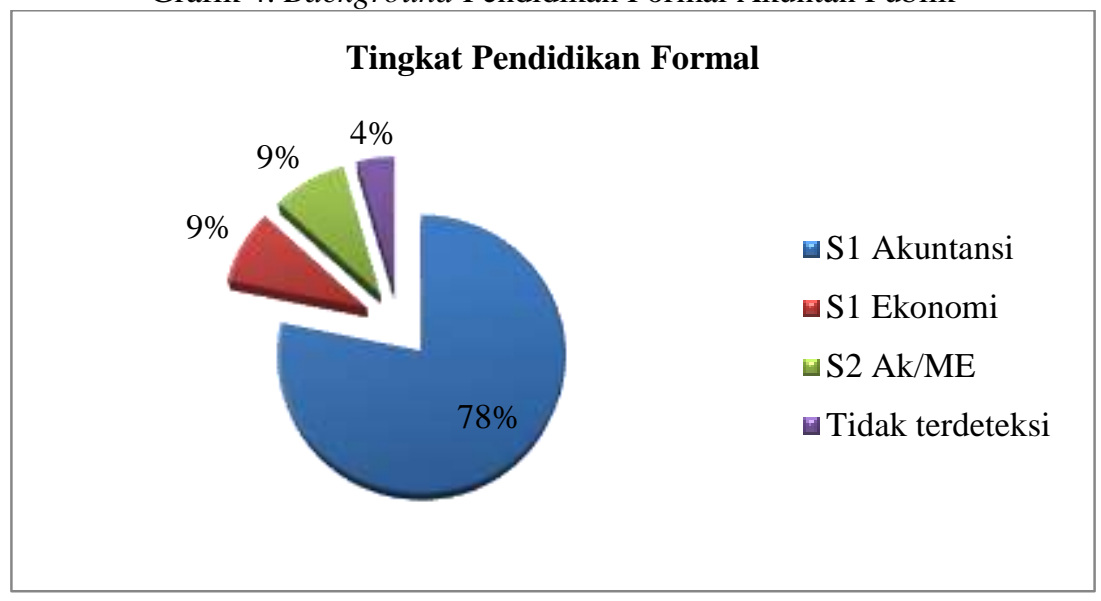

Sumber: Data diolah dari OJK(2016)

Dari grafik diatas dapat dilihat bahwa $78 \%$ akuntan publik memiliki background pendidikan formal sebagai Sarjana Akuntansi. Sedangkan 9\% masing-masing akuntan publik memiliki pendidikan akademik berupa Sarjana Ekonomi maupun Master Ekonomi.

Grafik 5. Sertifikasi Akuntan Publik

\section{Tingkat Pemegang Sertifikasi}

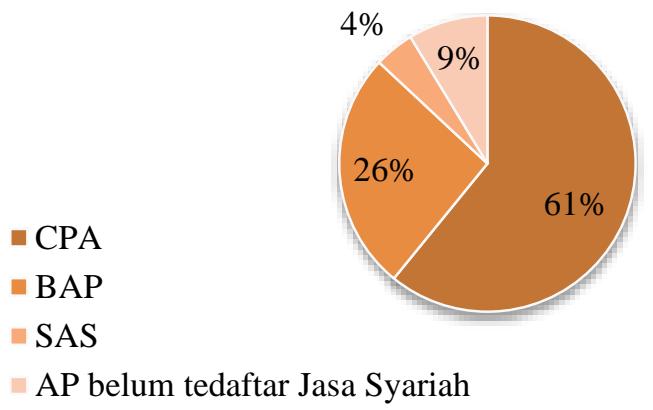

Sumber: Data OJK 2016 diolah 
Data grafik diatas diketahui bahwa $61 \%$ atau sebanyak 14 akuntan publik telah memiliki sertifikasi CPA, sebesar $26 \%$ selanjutnya memiliki sertifikasi BAP dan hanya $4 \%$ auditor yang memilki sertifikasi SAS. Dari sejumlah 23 akuntan publik yang bertanggung jawab untuk mengaudit laporan keuangan 12 bank umum syariah telah memilki sertifikasi profesional seperti CPA, BAP, CA, dan SAS. Persyaratan auditor untuk mengaudit bank syariah adalah telah memiliki sertifikat pendidikan/pelatihan dibidang perbankan syariah sesuai dengan ketentuan Surat Edaran BI No.7/57/DPbS tanggal 22 Desember 2005.Pemegang sertifikasi SAS bagi seorang auditor masih minim karena peraturan sertifikasi ini masih bersifat baru dan berada pada tahap pengembangan.

Grafik 6. Pengalaman Kerja Auditor

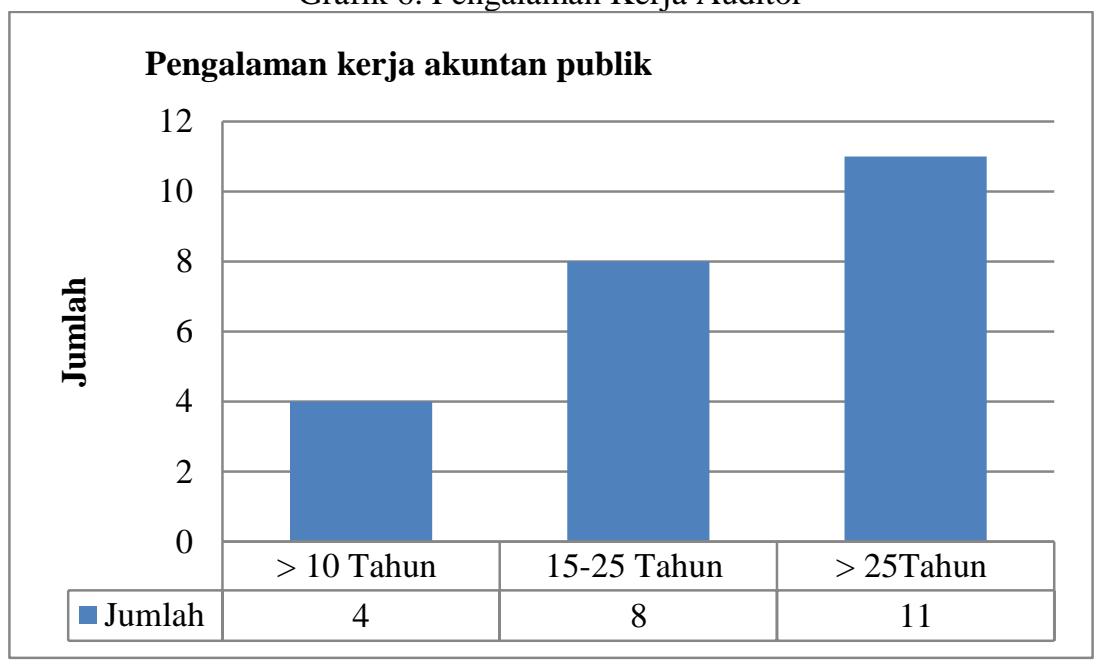

Sumber: Data OJK 2016 diolah

Data grafik diatas dapat diketahui bahwa jumlah terbesar akuntan publik yang memiliki pengalaman kerja dalam bidang akuntansi/auditing lebih dari 25 tahun sejumlah 11 orang. Rincian pengalaman kerja auditor dibidang ini meliputi sebagai manager maupun rekan KAP, menjadi auditor KAP, staff pengajar/dosen, account patner, supervisor dan komisaris PT Tugu Pratama Indonesia, menjabat sebagai kepala pengawas keuangan, direktur dan lainnya.

Penelitian yang dilakukan oleh (Saputra, 2012) bahwa kompetensi auditor berpengaruh signifikan terhadap kualitas audit. Indikator yang mendukung terpenuhinya kualitas audit yang tinggi karena beberapa alasan yaitu pertama, kebanyakan orang memahami bahwa semakin banyak jumlah jam tarbang seorang auditor, tentunya akan memberikan memberikan kualitas audit yang lebih baik daripada auditor yang baru bekerja (tidak memiliki pengalaman), ini akan membentuk keahlian auditor secara teknis dan psikis. Kedua, secara teknis auditor melakukan pekerjaan secara terus-menerus atau dikatakan frekuensi kerja yang lebih intens, maka auditor akan lebih handal 
untuk memahami bisnis klien, cara mengatasi masalah, mendeteksi suatu hal yang memerlukan keahlian khusus yang tidak diperoleh dari pendidikan akademik. Ketiga, secara psikis seorang auditor akan membentuk pribadi yang lebih cermat dan bijaksana karena pengalaman yang dilakukan membuat auditor lebih dapat memposisikan diri, sifat terus belajar dari fatalnya kesalahan, dan lainnya.

Grafik 7. Indikator Pelatihan Auditor

\section{Frekuensi Pelatihan Auditor}

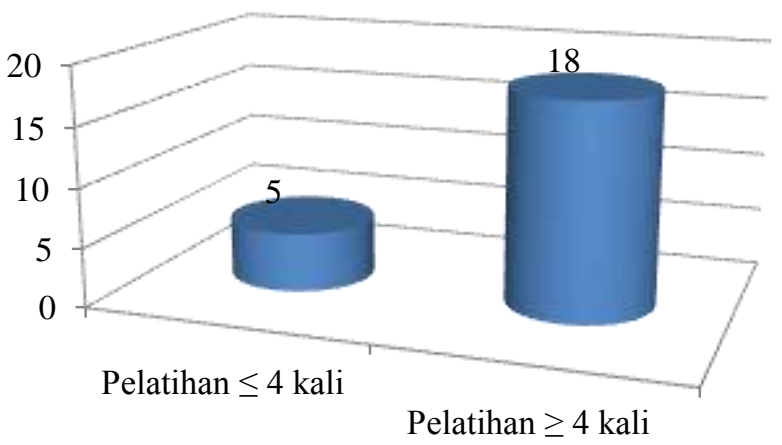

- Jumlah AP

\section{Banyaknya SKP Pelatihan Auditor}

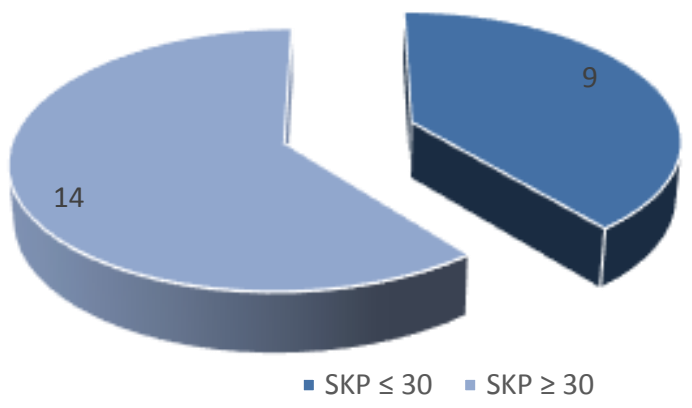

Sumber: Data OJK (2016) Diolah

Dari grafik diatas dapat disimpulkan bahwa frekuensi pelatihan auditor rata-rata lebih dari 4 kali. Pelatihan auditor berupa workshop penunjang karir auditor, pelatihan, seminar, dialog akuntan pasar modal, dan lainnya dalam bidang akuntansi dan auditing. Berdasarkan peraturan terbaru, 
jumlah minimum SKP pelatihan yang wajib diikuti oleh akuntan publik adalah 30 SKP. Informasi dari tabel diatas adalah sebanyak 14 auditor telah mengikuti PPL dengan 30 SKP lebih, artinya upaya auditor untuk menjaga kompetensi dengan mengikuti pelatihan profesi cukup lebih baik.

Jadi, ukuran kompetensi harus dihubungakan dengan proyeksiproyeksi seperti pengetahuan, pelatihan, pengalaman, dan untuk menunjang professional auditor maka diperlukan sertifikasi auditor yang memadai. Perkembangan lembaga keuangan syariah membutuhkan sumber daya manusia yang memilki kualifikasi tinggi. Namun masih banyak pakar yang tidak memilki sertifikasi syariah khususnya di bidang akuntansi.

Dinamika kualitas audit dilihat pada independensi dan kompetensi auditor. Kemampuan auditor mendeteksi kesalahan dalam laporan keuangan tergantung pada kompetensi auditor. Kompetensi auditor dan independensi memiliki hubungan dalam kondisi lamanya audit tenure. Kompetensi auditor berbanding positif dengan audit tenure artinya semakin panjang audit tenure maka kompetensi auditor semakin tinggi karenasemakin memahami internal control, sistem informasi akuntansi, dan risiko spesifik perusahaan klien. Pada tahun awal penugasan, kualitas audit masih rendah yang mungkin disebabkan pemahaman bisnis klien yang belum memadai, namun dugaan terhadap independensi auditor atas kedekatan terhadap klien akan mempengaruhi kualitas audit.

\section{SIMPULAN}

Perbankan syariah dalam menjaga kelangsungan usahanya harus menjamin terpenuhinya shariah compliance untuk meningkatkan kepercayaan publik. Perbankan syariah harus turut andil meningkatkan kualitas audit untuk tetap bersaing. Rotasi audit pada dua rezim mengundang banyak pendapat prodan kontra bagi akuntan publik. Hubunngan audit tenure yang panjang dengan munculnya peraturan rotasi wajib auditor memunculkan dinamika kualitas audit dalam berbagai penelitian. Audit tenure pada perbankan syariah telah memenuhi ketentuan peraturan pasca KMK (penetapan rotasi), dan perbankan syariah lebih nyaman menggunakan audit tenure daripada harus mengganti auditor setiap tahun baik rezim pada pasca KMK maupun pasca UU No.5 (tidak ada rotasi audit), sehingga peraturan rotasi audit yang diberlakukan pemerintah tidak memiliki pengaruh yang besar pada kualitas audit. Reputasi KAP berafiliasi Big Four lebih dipandang daripada non-big four sehingga fee audit meningkat setiap tahunnya. Namun, besaran fee audit tidak mengacu pada ukuran KAP walaupun kondisi besaran fee KAP big four lebih tinggi daripada non-big four. Dalam jangka panjang independensi auditor akan menurun karena ketergantungan ekonomi pada klien. Pengetahuan umum yang diperoleh dari backgroung pendidikan auditor, pengalaman kerja, pelatihan serta sertifikasi auditor membangun meningkatnya kompetensi auditor dalam keahlian menemukan kesalahan penugasan audit. 
Menurut peneliti dinamika kualitas audit dari hubungan independensi dan kompetensi auditor tergantung pada tingkat batas maksimal audit. Ketika awal penugasan audit sampai batas rotasi yang ditentukan maka peningkatan kompetensi lebih tinggi daripada penurunan independen hal ini dikarenakan auditor mulai memahami lingkup bisnis klien. Setelah audit tenure yang panjang lebih dari penetapan rotasi mengakibatkan masalah independensi yang lebih dominan mempengaruhi kualitas audit dari pada kompetensi kerena kedekatan emosional auditor dan klien sehingga mempengaruhi kualitas informasi yang disajikan.

\section{DAFTAR PUSTAKA}

Agoes, S. (2012). Auditing Petunjuk Praktis Pemeriksaan Akuntan oleh Akuntan Publik. Jakarta: Salemba Empat.

Akbar, T., Mardian, S., \& Anwar, S. (2015). Mengurai Permasalahan Audit Syariah dengan Analytic Network Process (ANP). Jurnal Akuntansi dan Keuangan Islam, 2(2), 101-123.

Alim, M. N., Hapsari, T., \& Purwanti, L. (2007). Pengaruh Kompetensi dan Independensi Terhadap Kualitas Audit dengan Etika Auditor sebagai Variabel Moderasi. In Simposium Nasional Akuntansi X Makassar (hal. 1-26). Makassar.

Association of Certified Fraud Examiners. (2016). Report To the Nations On Occupational Fraud and Abuse. USA. Diambil dari https://www.acfe.com/rttn2016/about/executive-summary.aspx\%0A

Baker, R. A., \& Al-Thuneibat, A. (2011). Audit tenure and the equity risk premium: evidence from Jordan. International Journal of Accounting and Information Management, 19(1), 5-23.

Coram, P., Glavovic, A., Ng, J., \& Woodliff, D. R. (2008). The Moral Intensity of Reduced Audit Quality Acts. AUDITING: A JOURNAL OF PRACTICE \& THEORY, 27(1), 127-149.

Elder, R. J., Beasley, M. S., \& Arens, A. (2009). Auditing and Assurance (7 ed). Singapore: Prentice Hall.

Fitriany, F., Utama, S., Martani, D., \& Rosietta, H. (2015). Pengaruh Tenure, Rotasi dan Spesialisasi Kantor Akuntan Publik (KAP) Terhadap Kualitas Audit: Perbandingan Sebelum dan Sesudah Regulasi Rotasi KAP di Indonesia. Jurnal Akuntansi dan Keuangan, 17(1), 12-27.

Gavious, I. (2007). Alternative Perspectives to Deal with Auditors'Agency Problem. Critical Perspectives on Accounting, 451-467.

Giri, E. F. (2010). Pengaruh Tenur Kantor Akuntan Publik ( Kap ) Dan Reputasi Kap Terhadap Kualitas Audit: Kasus Rotasi Wajib Auditor 
Di Indonesia. In Prosiding Simposium Nasional Akuntansi XIII Purwokerto (hal. 1-26). Diambil dari www.sna13purwokerto.com

Hariwibowo, I. (2013). Analisis Perbandingan Pengaruh Kualitas Audit, Likuiditas, Solvabilitas, Profitabilitas Terhadap Opini Audit Going Concern (Studi Perbankan Syariah Di Asia). STAR-Study \& Accounting Research, X(3), 51-67.

Hartadi, B. (2012). Pengaruh Fee Audit, Rotasi KAP, dan Reputasi Auditor Terhadap Kualitas Audit di Bursa Efek Indonesia. Ekonomi dan Keuangan Akreditasi No. 110/DIKTI/Kep/2009, 84-103.

Junaidi, \& Nurdiono. (2016). Kualitas Audit: Perspektif Opini Going Concern. Yogyakarta: CV Andi Offset.

Knechel, W. R., \& Vanstraelen, A. (2007). The relationship between audit tenure and audit quality implied in Going Concern Opinion. A Journal of Practice and Theory, 26(1), 113-133.

Law, P. (2008). An Empirical Comparison of NonBig 4 and Big 4 Auditors' Perceptions of Auditor Independence. Managerial Auditing Journal, 23(1), 917-934.

Manry, D. L., Mock, T. J., \& Turner, J. L. (2008). Does Increased Audit Partner Tenure Reduce Audit Quality? Journal of Accounting, Auditing \& Finance, 23(4), 553-572.

Pratistha, K. D., \& Widhiyani, N. L. S. (2014). Pengaruh independensi auditor dan besaran fee audit terhadap kualitas proses audit. E-Jurnal Akuntansi Universitas Udayana, 3, 419-428.

Rahayu, S. K., \& Suharti, E. (2010). Auditing Konsep Dasar dan Pedoman Pemeriksaan Akuntan Publik (Pertama). Yogyakarta: Graha Ilmu.

Republik Indonesia. (2008). Peraturan Menteri Keuangan Nomor 17 tentang Jasa Akuntan Publik (5 Februari). Jakarta: Lembaga Negara Republik Indonesia.

Republik Indonesia. (2011). Undang-Undang Republik Indonesia Nomor 5 Tahun 2011 Tentang Akuntan Publik. Jakarta: Lembaga Negara Republik Indonesia Nomor 5215.

Republik Indonesia. (2015). Peraturan Pemerintah RI Nomor 20 Tahun 2015 Tentang Akuntan Publik. Jakarta: Tambahan Lembar Negara RI Nomor 5690.

Saputra, A. E. (2012). Pengaruh Kompetensi dan Independensi Auditor teerhadap Kualitas Audit dengan Etika auditor sebagai Variabel Modifikasi. Jurnal Akuntansi, 1(2).

Singgih, E. M., \& Bawono, I. R. (2010). Pengaruh Independensi, Pengalaman, Due Professional Care dan Akuntanbilitas terhadap 
Kualitas Audit. In Simposium Nasional Akuntan XIII (hal. 1-24). Purwokerto: Universitas Jenderal Soedirman.

Tjun, L. T., Marpaung, E. I., \& Setiawan, S. (2012). Pengaruh Kompetensi dan Independensi Auditor Terhadap Kualitas Audit. Jurnal Akuntansi, 4(1), 33-56. 